\title{
An investigation into the ancient Egyptian cultural influences on the Yorubas of Nigeria
}

\begin{abstract}
Author:
Jock M. Agai ${ }^{1}$

Affiliation:

${ }^{1}$ School of Religion,

Philosophy and Classics,

College of Humanities,

University of KwaZulu-Natal,

South Africa

\section{Note:}

This article was completed as part of a $\mathrm{PhD}$ programme at the School of Religion, Philosophy and Classics in the College of Humanities at the University of KwaZuluNatal, under the supervision of Prof. Philippe Denis.
\end{abstract}

\section{Correspondence to:}

Jock Agai

Email:

leadershipserve@yahoo.ca

Postal address:

PO Box 11108, The Tramshed 0126, South Africa

Dates:

Received: 10 Jan. 2013

Accepted: 27 Apr. 2013

Published: 02 July 2013

How to cite this article:

Agai, J.M., 2013, 'An

investigation into the ancient Egyptian cultural influences on the Yorubas of Nigeria',

HTS Teologiese Studies/ Theological Studies 69(1),

Art. \#1919, 9 pages.

http://dx.doi.org/10.4102/

hts.v69i1.1919

\section{Copyright:}

C 2013. The Authors. Licensee: AOSIS OpenJournals. This work is licensed under the Creative Commons Attribution License.

Read online:
There are many cultural practices that connect ancient Egyptians to the Yorubas and the new interpretation of the Oduduwa legend suggests that the Yorubas have originated or are influenced mainly by the Egyptians. The attestation of Egypt as the main influencer of the Yoruba culture made Egypt significant in the study of the history of the Yoruba people. Some writers are beginning to think that the ancient Egyptians were responsible for introducing and spreading many cultures amongst the Yorubas. As more Yorubas are tracing their origins and the origins of their culture to ancient Egypt, this research investigates whether the Egyptians were the originators and the main spreaders of the afterlife culture in Yorubaland.

\section{Introduction}

\section{The problem}

In Yorubaland (south-west Nigeria), I have asked many Yorubas about their origins and about the origins of their culture. Most of the Yoruba people I interviewed told me that their ancestors originated in Egypt whilst a few said from Mecca. The Yorubas I met are aware of the Yoruba Oduduwa legend which says that the Yorubas are symbolically from the 'east' or 'Mecca'. ${ }^{1}$ Many Yorubas of today think that they rather originated in Egypt and not literally in the 'east' or 'Mecca' (Umoh 1971:116) and this prompted an investigation into the subject. This researcher has discovered that there are many cultural practices that connect the Yorubas to the Egyptians, ${ }^{2}$

1.Yoruba legend teaches that Lamurudu, the biological father of Oduduwa originally came from Mecca in Saudi Arabia to Ile Ife in Nigeria (Ayandele 2004:123). Oduduwa, a prince, wanted to change the state religion to that of idolatry worship. This resulted in a revolt
between Oduduwa followers and the majority of Muslims in Mecca. During the revolt, Lamurudu was killed and his children, including Oduduwa, were extradited and exiled from Mecca. Oduduwa and his children took with them two idols to lle Ife (Ojo 1999:5). Sahibu (one of the Islamic loyalists) and his army came with a copy of the Koran from Mecca and they followed Oduduwa to destroy or subdue him but were defeated and the copy of the Koran was taken away from Sahibu. Johnson (2001:4) says that the Koran was taken to the temple in lle Ife where it was venerated and later worshipped. To this day, it is called Idi, meaning something tied up. When he arrived at Ile Ife, Oduduwa he met with Agbo-niregun (or Setilu), the founder of Ifa worships (Johnson2001:4; cf. Folorunso 2003:87) yet much about the identities of those earlier inhabitants of lle Ife are unknown (Ayandele 2004:123). Many historians argue that the Yorubas actually originated from the north-eastern area of Africa and specifically Egypt or Yemen (Yemen used to be regarded as the horn of Africa [Le Roux 2008:15] and Yoruba historians associate Egypt with Yemen as if they were the same place). Lange (2004:40-41) agrees that the ancestors of the Yorubas were the descendants of Nimrod who lived and intermarried with Egyptians and then left Egypt and settled in Yorubaland. A prominent writer of Yoruba history, Reverend Samuel Johnson stressed that past historians regarded Egypt and settled in Yort Mecca as east and that there is indeed a strong affinity between the Yorubas and the east. He thinks that the Yorubas originate from the slightest doubt, as their habits, manners and customs, etc., all go to prove' (Johnson 2001:5). Folorunso (2003:84) agreed with the slightest doubt, as their habits, manners and customs, etc., all go to prove' (Johnson 2001:5). Folorunso (2003:84) agreed with (2001) and Folorunso (2003:84) think that Oduduwa had a diluted Coptic Christian background and that he was not a Muslim as it has (2001) and Folorunso (2003:84) think that Oduduwa had a diluted Coptic Christian background and that he was not a Muslim as it has
been speculated especially by the historian Uthman Belo. The Yoruba afterlife culture is different from that of the Arabs (the Yorubas been speculated especially by the historian Uthman Belo. The Yoruba afterlife culture is different from that of the Arabs (the Yorubas
for example practice extensive afterlife culture more than the Arabians) as discussed in this paper, and this indicates that despite the impacts of Islam on many Yorubas, yet their culture is more similar to the Egyptians than those of the Arabs in Mecca.

2.For example, Olorun the Yoruba god is credited with the attributes of being omniscient, omnipotent, and omnipresent. Lucas (1948:35) believes that the Yoruba word Orun means ' $\mathrm{k} k y$ ' and that 'O/ denotes ownership or agency so the word Olorun means 'Lord of the sky or of the heavens'. To the Egyptians, 'sky' or 'heaven' is called Horu and Lucas says that pre-dynastic and dynastic Egyptians referred to their Sun-god as Horu. He noted that Horu is derived from the word Oru(n), 'sky' or 'heaven', and that at the establishment of the Old Kingdom, Horu the sun-god was displaced by Horu (Horus) the younger, son of Osiris, the god of the dead and of the sky. With the transference of the Osirian heaven from Daddu to the sky, Osiris became 'the lord of the sky'. Lucas says that this title was With the transere of the (has that identity of meaning of Olorun with the title of Osiris constitutes a prima facie evidence for assuming the existence of some connection between the Olorun of the Yorubas and the Egyptian "Lord of Daddu". Lus reiterated that the Yorubas worshipped other deities but that Olorun was the greatest of them all and that the Egyptians regarded Osiris in the same way as the Yoruba Olorun (Lucas 1948:36-48) Lucas (1948:21) believes that most Egyptian gods like Osiris, Isis, Horus, Shu, Sut, Hathor, Sokaris, Ra, Seb, Thoth, Khepera, Amon, Anu, Khonsu, Khunum, Khopri and others are well known amongst the Yorubas. However, he noted that Ra survives only in name and that the Yorubas no longer worship the sun as the Egyptians did. Lucas further noted that many ancient Egyptian religious ideas have survived amongst the Yorubas: both ancient Egyptians and the Yorubas recognised the existence and the supremacy of a supreme deity but worshipped local deities. In both cultures, kings were regarded as divine authorities, certain animals as sacred and certain forms of festivals involving dancing and singing were practiced. Magic and the use of amulets were important in the daily lives and in the afterlife beliefs of both cultures (Lucas 1970:412-413). Also, the Egyptian word for hippopotamus is pronounced as Ririt from which the Yoruba word Riri, 'dirty' is derived. He thinks that the derivation is due to the dirty nature of hippopotami on emerging from marshy waters. Also, the sacred animal of the Egyptian city of On (Aunu) survives in the word Oni 'crocodile', a name used as the title of one of the paramount chiefs in Yorubaland, that is, the Oni of Ife (Lucas 1948:21-28). In addition, the word Orisa is used by the Yorubas to refer to the name of a supreme deity, a deity or an idol. Lucas says that the word Orisa is actually derived from the ancient Egyptian form Horu-sa-Ast or Horu-se-Ast (Lucas 1970:411-412). Lucas (1948:261) thinks that both the Egytians and the Yorubas Egyptian form Horu-sa-Ast or Horu-se-Ast (Lucas 1970:411-412). Lucas (1948.261) thinks that both the Egyptians and the Yorubas use the words Khu or oku to mean death. For example, he says that the Yorubas believe that every human being possesses a Khu or ' ku w' 'spirith "spirt' or 'spirtua sou' is Emi(n). Lucas (1948:261) believes that the Yoruba word Emi(n) is used in the same sense as the Egytian (hat the Yorubas regald Emi(n). Lucas (1988:261) connects the word $\operatorname{Emi}(\mathrm{n})$ can actually be transliterated to mean 'that which belongs to Min' the Coptos god of ancient Egypt. He thinks that the Yorubas had contact with Coptos in ancient Egypt, where the Egyptian deity Min was worshipped. In terms of knowledge, the Yoruba pottery, glass and glaze work and metalwork bear a close resemblance to those of dynastic Egyptians (Lucas 1970:414-416). The 'Ife Marbles' in Yorubaland have been found to have similarities to Egyptian sculptures. Johnson also reiterated that at present, about three or four of the forms of these sculptures can be seen in the Egyptian Court of the British Museum, 'showing at a glance that they are among kindred works of art' (Johnson 2001:6-7). Both cultures practiced polygamy and the first wife was given a special role and regarded as more important than the other wives. The Yorubas call her lyale, 'mistress of the house', a title corresponding in significance to the 
and this research concentrates on discussing the afterlife connection between these two cultures. However, are cultural similarities between two cultures enough reason to say that one of the cultures originated from the other or that one of the cultures influenced the other? Where does the Yoruba afterlife culture originate?

There are those who speculate that the Yoruba culture originated from Jewish sources (Lucas 1970:379, 382; Omolewa 2008:55). ${ }^{3}$ However, many Yoruba cultural practices do not have connections to those of the Israelites. Parrinder (1951:199) notes that there is virtually very little or no linguistic evidence that shows any form of connection between the Israelites and the Yorubas. ${ }^{4}$ In terms of the afterlife beliefs, the Israelites views and those of the Yorubas varied immensely ${ }^{5}$ and there is no clear oral history or literature analysis about any possible geographical evidence of migration from ancient Israel to Yorubaland. One of the greatest opponents of Egypt, being the main source of Yoruba culture, is Frobenius. Frobenius (1968) believes that the Yorubas were highly influenced by the Etruscan culture which passed through the Atlantic and centred itself in North Africa (Algeria, Morocco and Tunisia). Frobenius calls those Etruscan cultures which found their way into Yorubaland the 'Atlantic culture'. He rejects Egypt as the main influencer or as the geographical origin of the Yorubas. He based his hypothesis on the fact that there are many Etruscan cultural practices amongst North Africans that are similar to those of the Yorubas and he thinks that it was easier to travel from North Africa to Yorubaland than from Egypt to Yorubaland (Frobenius 1968:186-204). Frobenius says that the Yoruba and the Atlantic culture share:

- Water storage construction systems. He emphasised that the style of houses constructed by the Yorubas was

(Footnote 2 continues ...)

nabit piru (the mistress's crown) of the ancient Egyptians (Lucas 1948:28-30). It was believed in both countries that the magician and priest served the same function. For the Egyptians and the Yorubas, magic could be used in acts of love, passion, For the Egyptians and the Yorubas, magic could be used in acts of love, passion,
hate, ambition, revenge, healing and in other daily activities. Lucas believes that hate, ambition, revenge, healing and in other daily activities. Lucas believes that the magic and divination of the Egyptians has a strong connection linking them to the Yorubas (Lucas 1948:289290). Body mutilations practiced in ancient Egypt also
found their way to the Yorubas. These practices include: circumcision, excision, found their way to the Yorubas. These practices include: circumcision, excision,
piercing of ears and nose, tattooing, and shaving. These Yoruba cultures were practiced during the pre-dynastic and dynastic periods of ancient Egypt (Lucas 1970:412-413). Yoruba social engagements like salutation, respect for elders, importance of oaths, and observance of moderation were similar to those in ancient Egypt. It is also clear that both the Egyptians and the Yorubas shared names, for example, Danga is a name of a dwarf in ancient Egypt and this name also survives in Yoruba (lo bi danga ) meaning go as quickly as a Danga dwarf. The Yoruba clothing of animal skins especially of leopards is a pre-dynastic and dynastic Egyptian practice (Lucas 1970:414-416).

3.Lucas (1970:381-382) observed that in regard to animal sacrifice, ablution, purification and marital norms, the Jews did like the Yorubas, yet he noted that this is not enough reason to conclude that the Yorubas are culturally influenced or are is not enough reason
originated from Israel.

4.Parrinder believes that Egypt made some impact on the Yorubas but that Islam made more impact on the Yorubas than any other culture (Parrinder 1951:205-209).

5.Ancient Israelites had varied views and much uncertainty about the afterlife. They were not keen to know and particular about what would happen to them in the afterlife. The Israelites used to view Sheol as the home of the dead and they though of it differently depending on the situation in which they found themselves. For example, initially, there was no idea of punishment of the wicked or reward of the righteous in Sheol. Rather, Sheol was perceived as a dwelling place for all the dead (Gn 37: 35; 42: 38; 44: 29). Nevertheless, there was another notion of Sheol as

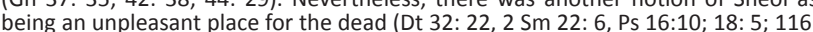
3). There were also instances whereby Sh $32: 22,2$ Sm 22: 6, Ps 16:10; 18: 5; 116 : 3). There were also instances whereby Old Testament (Job 24: 19, Ps 55:15, Pr 7:27; 15:11, Is 14:15; Ezk 18:20). Translator of the Authorised King James Version sometimes used the word 'hell' for Sheol as in Psalm 16:10; 18:5 and Proverbs 7:27 (Agai 2011:195). The Yorubas on the other hand, are certain that the wicked would be punished in the afterlife until they are reincarnated, and they regard the afterlife world with great prestige especially if the deceased lived a good life style on earth. similar to those used by the Etruscans, Moroccans and Algerians whereby the Impluvium is built in the centre of the house whilst apartments with verandas are built in a rectangular form.

- The construction of their houses. Yorubas construct houses with ridge roofs that are similar to those in North Africa.

- The colour and form of bows and arrows used by the Yorubas are similar to those in Morocco.

- The North African hand loom, unknown in the Sudan, is found amongst Yoruba woman.

- The drum shape and other articles peculiar to North Africa are not found in the Sudan, but are found in Yorubland.

- The existence of the 'Templum', amongst both the Yorubas and North Africans whereby houses are built round a temple or sacred building; even in towns, houses were generally built around sacred buildings. Frobenius thinks that even the religion of Ile Ife is based on the 'Templum' idea (Frobenius 1968:336).

The criterion that Frobenius used to conclude that it was easier to travel from North Africa to Yorubaland than from Egypt to Yorubaland is not known. Frobenius's archaeological findings particularly when comparing certain articles and house-forms between North Africa and the Yorubas, are true (Lucas 1948:348), ${ }^{6}$ but his conclusions still raise some questions. Firstly, these same Etruscan elements like the hood loom, arrow, Impluvium, Templum and others listed by Frobenius are also widely used in Egypt but Frobenius did not explain how these cultures found their way into Egypt. The presence of Etruscan elements in both Egypt and North Africa suggest that these regions (Egypt and North Africa) were earlier influenced by these elements through their contact with the Etruscans. Lucas (1948:349) says that Frobenius's view that all monuments of the ancient Atlantic culture are placed on the coast (Frobenius 1968:336) can also be questioned because important Yoruba places like Ile Ife and Offa where these monuments (Etruscan articles) were found are about two hundred miles away from the coast (Lucas 1948:349). As a result, Lucas (1948:351) believes that the Etruscan culture did not originate in Egypt yet the culture passed through Egypt and from there to Yorubaland.

The limitation concerning this subject is that there are rather very few authors who discussed possible Egyptian cultural influences on the Yorubas, amongst them are Folorunso, Lucas Olumide, and Reverend Samuel Johnson. It is likely that the absence of archaeological evidence for contact between ancient Egypt and Nigeria (Parrinder 1951:200) is one of the reasons for discouraging contemporary research into this possibly 'new' field of study. ${ }^{7}$ There is a need to

6. However, Lucas (1948:35) thinks that these Etruscan influences on the Yorubas only occupied a very small portion of the Yoruba culture.

7.Some historians and archaeologists do not believe that Egyptians migrated to Nigeria; rather they think that Egyptian migrants stopped their journeys at the Sudan and some parts of Senegal. Maram Mafulul believes that the Nigerian tribes are of Niger-Congo origins and not Egypt. Mafulul thinks that there is no archaeological Niger-Congo origins and not Egypt. Mafulul thinks that there is no archaeological
evidence that supports Egyptian presence in Nigeria and in his view oral history and evidence that supports Egyptian presence in Nigeria and in his view oral history and legends should not be given credence in scientific research. Mafulul's hypothesis
failed to recognise that West Africa had a setback in documenting its history and in the preservation of its possible archaeological evidences or sites hence the need in the preservation of its possible archaeological evidences or sites hence the need
to give some attention to oral history. These deficiencies should rather serve as an opening for further academic inferences and as a check for scholars who 
stir interest about this subject because of the significance of the Yorubas and of the Egyptians in understanding African anthropology. ${ }^{8}$ The aim of this research is not to discuss in detail all that the afterlife entailed for both cultures but to investigate (by comparing the two cultures) whether the Egyptians were responsible for originating or influencing Yoruba afterlife culture and to open up a new debate into the study of ancient Egyptian-Yoruba connections.

\section{Egyptian-Yoruba afterlife connection}

\section{Burial rituals}

The ancient Egyptians believed - as the Yorubas do - that a befitting burial for the deceased affects the relationship between the living and the dead. The Yorubas and ancient Egyptians believed that a good burial attracted fortune for the bereaved and the deceased and that a bad burial attracted misfortune for the bereaved and for the deceased (Lucas 1948:253). Both cultures believed that the burial of a loved one is a family and community engagement. Burial processions involving a priest, relatives, the first son and other children of the deceased as well as well-wishers were significant to both traditions. The social role of people in this life is assumed to be maintained in the afterlife by both cultures. Kings would continue to rule and servants would continue to serve their masters in the afterlife, likewise farmers, iron smelters and all people of various professions thought that they would continue with their professions in the afterlife (Adamolekun 2001:610; El-Shahawy 2005:78).

In addition, in both ancient Egypt and amongst the Yorubas, servants, wives of kings, and loyalists of leaders were buried together with their masters (Awolalu 1979:56-57). At a later stage, sculptures images and animals' blood were used for

(Footnote 7 continues ...)

often make impromptu conclusions on the history of West African tribes. Maram Mafulul master's degree in archaeology at the Ahmadu Bello University Zaria Nigeria is being examined at the time of writing. He wrote intensively on 'Ancient Iron Smelting among the Mahurum People of Bokkos in North-Central Nigeria.' Our discussion concerning his research subject was held on 16 January 2013. 8. Egypt is a significant nation in Africa for many reasons, one of which is the
abundance of evidence of their ancient practice of the afterlife. For example, the abundance of evidence of their ancient practice of the afterlife. For example, the
discovery of the 'Valley of the Kings' in ancient Thebes reveals so much about their afterlife beliefs. In Tutankhamun's tomb, in addition to his mummified remains, ove 2000 items which included three golden funerary couches in the shape of animals, boxes of funerary figures, ivory game boards and in the burial chamber, two statues representing the Pharaoh's $K a$, that is, his spirit or soul, were found. Inside the burial chamber were four shrines covering the sarcophagus with its three inlaid coffins made of gold in the image of Tutankhamun (Scheffler 2000:117). Next to the burial chamber was another room guarded by Anubis (a jackal-god whose job was to protect the embalmed deceased). This room contained canopic jars which were guarded by the goddesses Serket, Isis, Nephthys and Neith. The most astonishing guarded by the goddesses Serket, lsis, Nephthys and Neith. The most astoning item found was the beautiful mask that covered the face of Tutankhamun. The mas is made up of beaten gold, measures about $54 \mathrm{~cm} \times 39 \mathrm{~cm}$ and weighs $11 \mathrm{~kg}$ with a necklace collar which consists of rows of lapis lazuli, coloured glass beads, quart and amazonite. The eyes of the mask are made of quartz and obsidian whilst the eyelids are of inlaid blue glass. The brow is made in the shape of a vulture head and the uraeus (sacred serpent). The mask also has a plaited beard which turns up at the end and is made up of coloured glass held in a framework of gold (Scheffle 2000:119). A number of heart scarabs with amulets have also been found in Egypt. One of the amulets is said to have belonged to the mummified King Sobkemsa of the early Seventeenth Dynasty (James 1976:159). The ancient practice of mummification, the acts of burial with funerary objects like water, food, canopic jars, charms and the burial of a king together with his or her loyalists in ancient Egyp puts Egypt in the limelight with regard to the research of African cultures. Egypt was and remains one of the greatest lands of attraction on earth, hosting hundreds and thousands of tourists and researchers daily. The Yorubas on the other hand are strong homogenous group in Nigeria many of whom are also indigenes of Togo and strong homogenous group in Nigeria many of whom are also indigenes of Togo and the Benin Republic. Many Yorubas are better educated (Ayandele 2004:121) than the other two major tribes (Ibos and Hausas) in Nigeria (Ayandele 2004:121). The Yorubas have conducted more academic work than other African tribes with regard to their cultural, social, and educational values. Their levels of education have made so many of them well-placed in significant formal and informal positions all over the world. They are being described as 'the most outstanding people of "Black Africa" with respect to their myths' (Lange 2004:39) burial to represent the king's loyalists amongst the Yorubas, just as the Egyptians who began to bury their loved ones using images and statues in order to represent the king's loyalists. Because death was regarded as a journey, ancient Egyptians buried their leaders together with items like clothing, ceremonial oils, canopic jars, water, food and charms (James 1976:158-159). Likewise, the Yorubas bury their kings and wealthy people with items like clothing, food, water, jewellery, silver and money (Awolalu 1979:5657). Although the Yorubas do not build pyramids in which to bury their loved ones as was done in Egypt, the Yorubas believe that they should bury their leaders, their parents and their loved ones in the most acceptable way by undergoing all the traditional burial rituals. Like the Egyptians who, at a later stage, began to enlarge the size of the graves of their leaders in order to include burial goods (Murnane 1992:35; Partridge 1994:6-7), likewise, the Yorubas enlarge their graves to accompany burial goods (Awolalu 1979:56-57). Some Predynastic Egyptians wrapped the bodies of their deceased in mats (James 1976:155) just as the Yorubas did in the past (Awolalu 1979:172).

Although both the Yorubas and the Egyptians regarded the heart as the 'seat of intelligence' some Yorubas remove the heart of a deceased, not to be stored in a canopic jar as it was done in Egypt (Otey 2004:1), but to be eaten by the king's successor and, in this case, the heart signifies the deceased's divinity and power which will be transferred to his successor (Lucas 1948:252-253). The Egyptians, on the other hand, removed all other internal parts of the deceased body leaving behind the heart inside the body which they believed would be judged in the afterlife (El-Shahawy 2005:75-77; James 1976:157-160). For the Yorubas, the heart plays a greater role in the afterlife than the body which they believe will dissolve at death. For the Egyptians, the deceased body was equally important because they believed it would resurrect in its physical form hence the mummification of bodies (Partridge 1994:8). Both the Egyptian and Yoruba traditions attribute a degree of significance to the human heart; they both regarded the heart (of especially leaders) as an organ that has some symbolic life authority or an inheritable divinity in the afterlife.

\section{Harmful spirits of the dead}

The Early Egyptians also believed that the spirit of the deceased lived amongst the living but the Yorubas are more concerned about the ability of the spirit of the dead to either help or harm the living (Adedeji 1983:117; Adamolekun 2001:611). The Yorubas fear the spirit of the dead. The Egyptians did not fear the spirit of the dead. They served the dead and prepared for their death just to seek a good afterlife and not because they feared the spirit of the dead (Wayne \& Simonis 1994:15). Jordan says the belief that curses upon the living by the dead was never deeply ingrained in the Egyptian spirit (Jordan 1976:150). The Yorubas fear the spirit of the dead in almost the same way that they fear God. I think that Egyptians had less regard for ancestor worship, reincarnation, transmigration and the fear of the spirit of the dead than the Yorubas who have a high regard for these beliefs. 


\section{Mummification}

The Yorubas do not mummify or keep the deceased bodies dry as was done in Egypt and this could be why Lucas (1948) comments that:

although the Yorubas believe in the preservation of their deceased bodies, the majority of Yoruba tribes did not regard the preservation of the deceased body as highly important as did the Egyptians. (p. 253)

This is why there is little or no evidence amongst the Yorubas regarding the practice of mummification (Lucas 1948:253). There is now virtually no evidence to prove that the Yorubas mummify or have mummified in the past and, even if they did, it was not done in the same way it was done in ancient Egypt. This view is supported by Parrinder (1951:205) who believes that mummification is the one striking difference in burial rituals between the ancient Egyptians and the Yorubas. But he thinks that some West Africans practiced a kind of mummification differently. Contemporary and wealthy Yorubas preserve their deceased loved ones in modern mortuaries for long periods of time whilst preparing for their burials and it seems their penchant for preserving corpses for a long period of time is closely related to those of the ancient Egyptians. ${ }^{9}$

\section{Reincarnation}

Like other Africans, ancient Egyptians believed in reincarnation, but there is rather very little evidence concerning how they regarded reincarnation and transmigration. Parrinder $(1951: 116,205)$ believes that there are very few traces of the concept of reincarnation amongst ancient Egyptians. The Yorubas, on the other hand, regard reincarnation in high esteem. They believe that it is an honour to be reincarnated and there is no evil connotation attached to those who are reincarnated except for the Ogbanje $\mathrm{e}^{10}$ (Asakitikpi 2008:59-60).

\section{Afterlife journeys}

The Yoruba concept of the location of the world of the dead varies. Some Yorubas think that there is a long journey that awaits all the dead and that this journey involves the crossing of a river. In that river, a ferry man has to be paid to allow the deceased to cross over (Awolalu 1979:57-58). The Egyptians, on the other hand, associated the transporting of a corpse for burial with the crossing of the River Nile using a boat. The Egyptians also linked the resurrection of the dead to the seasonal tides of the Nile (El-Shahawy 2005:75-77). The Egyptian view of crossing the river by a deceased differed from Yoruba traditions, yet both cultures regarded crossing a river as a part of a journey into afterlife. On the route to the final destiny of the dead, the Yorubas believe that the afterlife journey involves a mountain which the deceased must climb

9.Ancient Egyptians preserved their deceased loved ones because they thought the dead would rise, the preservation allowed them time to prepare for a befitting burial and it gave the bereaved some comfort to believe that their dead lived. This kind of attitude where the bereaved think that certain rituals enable their deceased to live happily in the afterlife is the same attitude that seems to be guiding the to live happily in the afterlife is the same attitude that seems to be guiding
Yorubas to preserve a corpse for a long period of time in modern mortuaries.

10.Ogbanje are regarded as spirits. The Yorubas believe that lazy human beings who died will be returned to earth so they can repent. Whilst on earth, they could caus misfortune to the living and are referred to as Ogbanje (Asakitikpi 2008:59). or that there is a gate keeper who watches over the gate to the world of the dead. Some say that the final destiny of the dead is located beneath the ground yet others believe that the abode of the dead is invisible and partitioned from the world of the living by a thin object which means that the dead are close to the living (Awolalu 1979:57-58).

The Yorubas believe that the dead go and live in certain villages and market places within the geographical boundaries of Yorubaland. Whenever they are noticed by anyone who knows them, the deceased immediately leave for another destination (Awolalu 1979:57-58). Unconfirmed stories from pupils whose parents died without them knowing, suggest that they have just been visited by the same parents who have died (Awolalu 1979:58). There are Yorubas who claim that the dead visit them in the physical form and not as spirits. According to Yoruba tradition, there seem to be various locations for the dead, yet many Yorubas generally believe that the dead first go to Olódùmarè [God who judges], the source from where the Supreme Being disposes the dead to his (Olódùmarè's) preferred location (Awolalu 1979:58).

Furthermore, the Yoruba people believe that there are two heavens in the same way as the Egyptians did. The Egyptians believed that one of the heavens was more comfortable than the other and the Yorubas also believe that one of the heavens is good but the other one is the same as Hell, a disrespectful abode for the dead (Ade 2006:12;11 Murnane 1992:43). The Yoruba concept of 'hell' or the 'Heaven of Potsherd' which is associated with suffering, wandering, thirst and hunger is the equivalent of the Egyptian netherworld (Ellis 1966:127128; Lucas 1948:256). The other destiny of the dead called 'the land of the dead' or Deadland ${ }^{12}$ has been portrayed as a place where the social roles of people on earth is continued to be played. The land of the dead has been portrayed as a distant place to journey to, hence the need for food and water offerings. The Yorubas believe that the social role of a deceased is considered to be replayed in the afterlife as is done in the good Heaven. Egyptians also believed that the social roles of people on earth would continue to be played in heaven and they believed that food and water offerings helped the dead to complete their afterlife journey successfully (Ellis 1966:148-150).

Ancient Egyptians believed and regarded heaven as a pleasant place where kings would continue to be kings. The Yorubas also have these beliefs regarding heaven. The Egyptians believed - as do the Yorubas - that proper funerary rites would enable the deceased to enjoy his or her stay in heaven or Deadland. Like the Yorubas who believe in specific destinies where the wicked would live and be blessed or punished, the Egyptians believed that the most difficult thing after death is the journey of the deceased soul through the desert and the dark netherworld. Ancient Egyptians

11.The idea of heaven as a pleasant place in Yoruba culture was emphasised by Ade (2006).

12.The Yoruba concept of a 'Deadland' describes a place where all the dead go, this place is known to be a place of weakness, unproductiveness, and it gives a general place is known to be a place of weakness, unproductiveness, and it gives a genera
view of the Yoruba concept of journey and the waiting, or final residing place view of the Yoruba concept of journey and the waiting, or final residing place
of the dead in the afterlife, depending on whether the deceased deserve to be reincarnated. 
thought that $R e$ would save certain people who were loyal to the laws of order from suffering in the netherworld which would be a temporary experience (Davies 1999:27). There exist more similarities than dissimilarities regarding the afterlife beliefs between the Yorubas and ancient Egyptians but why do these similarities and differences exists? Did the ancient Egyptians actually migrate or have contact with the Yorubas? If yes, who influenced whom between these two cultures and if not, where is the origin of the Yoruba culture?

\section{Did the ancient Egyptians have contact with the Yorubas?}

Both the Egyptians and the Phoenicians travelled to West Africa for adventure, in search of slaves, ivory, incense, gold, and other minerals (cf. Boshoff \& Scheffler 2000:38; Clark 1970:15, 219; Lange 2004:277, 279; Le Roux 2008:7). They travelled by sea and by land. When they travelled by sea, their boats were made to sail on the Nile (Burland 1957:61-62). Many writers of West African history believe that Egyptians did travel to Nigeria. It is debatable whether they trekked or they used camels or donkeys to travel. The specific routes those Egyptians chose and the exact distance between ancient Egypt and Nigeria either by road or by sea is unknown except by modern means. The lack of or the fact of insufficient archaeological evidence surrounding the theory of migration between Egypt and Nigeria has made researchers to rely on very few historical documents, informed speculations, oral history and the evidence of probable remnants of Egyptian culture in Yorubaland.

For example, Etruscan culture ${ }^{13}$ found its way into Egypt, North Africa and Yorubaland. Both Lucas and Frobenius agree that it is true that elements of Etruscan culture found their way to the Yorubas either from Egypt or from North Africa to Yorubaland. But the routes through which those elements of Etruscan culture found their way into Yorubaland remains the bone of contention. Lucas (1948:351) believes that Etruscan culture did not originate in Egypt, yet the culture passed through Egypt and from Egypt to Yorubaland. Lucas (1948:351) noted that Etruscan communities called Turs or Tursh or Turishas actually lived in ancient Egypt and this made it possible to assume that Etruscan elements travelled along with ancient Egyptians to Yorubaland by way of the interior, that is, through the Sudan. Lucas (1948:352) thinks that it was possible to travel by sea and also by road from Egypt straight to the Sudan and to Nigeria without first passing through North Africa. Lucas (1948) says that:

evidence is available that the transmission of the ancient Egypt culture followed a trans-continental route from Egypt to the western shores of Africa. (p. 352)

In order to backup his argument, Lucas presented the views of Sir Wallis Budge who said that during the Persian wars with Egypt, Herodotus testified to the fact that over 20000 cities lined the banks of the Nile and expressed the opinion that people must have gone to West Africa from Egypt (Lucas 1948:349). After his research on the subject under study,

13.The Etruscans are regarded as seafaring people who came from Asia Minor and resided in Italy as early as 1000 BCE (Roberts 2013).
Parrinder (1951) traced probable routes of communication from the Upper Nile, skirting the tropical forest eastward along the Sudan to the old western Sudanese kingdoms, such as Gao, Ghana, Djene, Timbuktu (in Mali) to the coast of Guinea and the Bight of Benin (in Nigeria):

The gap of desert between the Upper Nile and Nigerian Sudan is now impassable except by modern means of transport owing to the lack of water, but there are signs of ancient wells, at intervals, that might have allowed a crossing in the distant past ... hence there may have been earlier communications, possibly in the pre-dynastic and early dynastic Egyptian periods (Parrinder 1951:198).

This contradicts Frobenius's notion, who said that Etruscan culture did not pass through the interior (Sudan). One of the main reasons for Frobenius's rejection of Egypt or the North-East as the main influencer of Yoruba culture is that, he thinks there is no historical backing that supports a route by land or by sea which shows any convenient form of migration between Egypt, through the Sudan to Yorubaland but he thinks that one exists from North Africa directly to Yorubaland. Frobenius believes that North Africa interacted more with the southern fringe of the Sahara than Egypt did (Frobenius 1968:325-326; cf. Lucas 1970:400). ${ }^{14}$ Frobenius's exclusion of the Sudan as a route for the transfer of Etruscan culture to Yorubaland has been prompted by the fact that these Etruscan elements are not found in the Sudan.

Moreover, Lucas (1948:351) suggests that the absence of similar cultures in the Sudan can be explained by the supposition that immigrants from Egypt (who carried with them some kind of Etruscan culture) would find it hard to settle in the arid desert of the sub-tropical climate of the Sudan and that the influence of the Etruscans from Egypt could only be felt permanently in Yorubaland, where geographical conditions support a prolonged visit or temporary settlement (Lucas 1948:351). Burland (1957:62) also noted that the hot swampy nature of the Sudan which attracted other Negros and the Egyptians for trade was not attractive for the permanent settlement of those Egyptians. ${ }^{15}$ This researcher supports the view that there could have been a possible migration of Egyptians from Egypt through North Africa to Nigeria but favours the Sudan routes for the following reasons: ${ }^{16}$

- Sudan was a part of the political empire of ancient Egypt hence communication was made easier. The ancient kingdom of Kush, a name given to the kingdom which lay to the southern borders of ancient Egypt spread over

14.Phoenicians had influenced North Africa, for example, evidence of Canaanite language and culture was found to be practiced amongst the Berber people of North Africa (Lange 2004:267, 277). Epigraphic and archaeological remains attest to the fact that the Phoenicians settled in the interior parts of North Africa which include areas such as Fezzan which is an extended oasis of the Lake Chad region in West Africa. Punic inscriptions found in Garama support the view that there was a spread of Canaanite tradition in North Africa and some regions of Lake Chad (Lange 2004:277). Some northern parts of Nigeria like Borno were regarded as a region of Lake Chad (Lavers 2004:187). The presence of the Phoenicians in North Africa and Lake Chad (Lavers 2004:187). The presence of the Phoenicians in North Africa and from Egypt to both North Africa and to Nigeria.

15.Cf. Clark 1970:16

16.Lucas (1970:400-401) says that the Nigerians went for pilgrimage in Egypt many centuries ago and this implies a possible early migration routes from between these two cultures. 
what is referred to today as the Republic of Sudan (both north and south) and like Egypt, depended on the Nile for its life (Shinnie 1965:23).

- The fact that the Nile flows into the Sudan (Jordan 1976:26) could have allowed easier access from Egypt to Sudan.

- Some of the Phoenicians who went to Egypt in search of gold, metals, weapons, textile and slaves extended their search to Central Sudan from Egypt (Boshoff \& Scheffler 2000:38; Lange 2004:277-278). Because the Phoenicians passed through the Sudan, it thus suggests that there was a route and perhaps an easier or convenient route from Egypt to Sudan. The fact that Egypt depended on the regions across the upper Nile, Dafur and West Africa for the supply of Black slaves (Lange 2004:279) suggests that Sudan was convenient for travel to Nigeria. However, whether the Sudan route or the North African route was used in preference by those Egyptian migrants, it is said that they all passed through Lake Chad until they arrived at the other regions of Nigeria. Lange (2004) says that these were the preferred routes for those traders:

the central Saharan route leading from Tripoli via Fezzan and Kawar to Lake Chad may also have been in ancient times the main provider of black slaves either by way of Leptis Magna, its direct Mediterranean outlet, or indirectly via Carthage or Egypt. (p. 279)

The Kingdom of Kanem Borno was part of Lake Chad, a place to which both Phoenicians and Egyptians travelled (Lange 2004:280, 284). The old empire of Kenem comprised parts of the Republics of Niger, Chad, Cameroon and Nigeria (Lavers 2004:187). In the past, Borno was regarded as a region of Lake Chad (Lavers 2004:187). The most serious challenge concerning this research is the absence of geographical evidence about the specific migration routes assumedly used by the Egyptians especially from Egypt to Kenem-Borno, and from Kenem-Borno to Yorubaland. Even though there may have been contact between ancient Egypt and Nigeria, yet there is no specific evidence of specific individuals who came from Egypt to form the Yoruba race or lived in Yorubaland. The Yoruba culture is unique itself and is comparable to no other tribe in Nigeria (Shinnie 1965:79). Thus where and how did the Yoruba afterlife culture found its way into Yorubaland?

\section{The origins of the afterlife beliefs From early humans}

In this research, it is alleged that the culture of modern humans has been derived from the cultures of early humans. The technicalities in detail involving the transmission or transfer of the afterlife beliefs from early human ancestors to modern humans are beyond the scope of this study. However, Neanderthals are discussed in detail due to their relevance with regard to the origins of the afterlife beliefs. Homo is a term used to designate the genus of different hominid species from which man is said to have originated (Agai 2005:62-70) and according to the biological theory of human evolution, there exist three species of early humans, namely Homo heidelbergensis, Homo neanderthalensis
(Neanderthals) and Homo sapiens. ${ }^{17}$ Homo heidelbergensis was found in Germany in 1907. Generally, H. heidelbergensis had a thick ridge over the eye socket, a large brain, a forehead, a nasal bone similar to $H$. sapiens, and a bony ridge that ran along the midline of the skull. Raven and Johnson (1999:458) say that $H$. heidelbergensis originated from Ethiopia about 600000 years ago.

Homo neanderthalensis arrived in Europe from Africa about 13000 years ago. Neanderthals flourished during the Last Ice Age, they possessed a strong jaw and were generally powerful and intelligent. They hunted, made tools, cooked and lived mostly in caves. Despite the mental powers found in $H$. neanderthalensis, they were neither farmers nor livestock keepers (Wadud 1971:206-207). The emergence of modern humans started when Neanderthals were replaced by $H$. sapiens. Some species of early humans are said to have originated from H. neanderthalensis (Jordan 1976:28). Many archaeologists are of the opinion that there is now good evidence that the Neanderthals themselves have evolved directly into modern humans (Leakey 1982:60), and some went as far as to say that they could believe that Neanderthals were humans and not some forms of animal-like beings which evolved to modern humans (Constable 1973:97). The Neanderthal man is significant in the study of early human culture because of the way it is said that they valued religious practices and were intelligent in their activities. They had good communication system (Clark 1970:145-146), they made caves wherever they found themselves and they lived a social life and were skilful in the use of tools (Caldwell \& Gyles 1966:9). Such cultural and technical proficiencies made researchers begin to associate almost all remains that have religious significance to the Neanderthal man (Hultkrantz 1982:22).

Archaeologists have found the burial remains of Neanderthals in numerous graves in different parts of the world, these include: Neander Valley in Germany, Spy in Belgium, the cave of La Chapelle-aux-Saints in France, Shanidar cave in northern Iraq (Constable 1973:97-101), Dire Dawa in eastern Ethiopia (Clark 1970:120), and the limestone cave in Greece, and in many more places (Leakey 1982:52-53). Inside these graves, evidence was found of food offerings to the dead and burial goods like awls and scrapers. MacGregor (1992:55-56) says that Neanderthals buried their loved ones together with flint implements and that they continued to serve food to the dead. This suggests that Neanderthals thought that death was

\footnotetext{
17 The only surviving Homo and hominid is $H$. sapiens. They have a skull modern in appearance, a vertical forehead with a brain that is both high and short. The in appearance, a vertical forehead with a brain that is both high and short. The
brain capacity is almost the same as that of modern man; it's about 1550 cubic centimetres (Raven \& Johnson 1999:458). At the beginning of the last Ice Age in Europe, $H$. sapiens began to encroach upon Neanderthals and displaced them entirely before the end of the last ice age. Some interbreeding took place between these two human ancestors such that when the ice receded, no trace of Neanderthal tradition remained. Homo sapiens were found in Europe, Africa and Asia (Caldwell \& Gyles 1966:12). One major example of early sub-race people was the CroMagnon people who were rather tall with dolichocephalic skulls (long heads). CroMagnon was a member of the modern living species and a $H$. sapiens (Caldwell \& Gyles 1966:14). Cro-Magnons originated in Africa and used sophisticated tools \& Gyles 1966:14). Cro-Magnons originated in Africa and used sophisticated tools made of stones and bones. They had a unique social organisation and possessed the ability to speak. The drawings in their caves showed them as hunters. Raven and Johnson (1999:458-460) say that the Cro-Magnon people also interbre with Neanderthals until they replaced the Neand ocial life, the communication skils, their beliefs, their ability to manufacture and use tools makes $H$. sapiens species and $H$. neanderthalensis in particular of great significance in the study of the origins of human beliefs.
} 
a continuation of life, a journey to another realm and that the dead needed to be fed on this journey (MacGregor 1992:5556). Caldwell and Gyles (1966:9) also say that these burial activities of the Neanderthal found by archaeologist indicate for the first time a culture of ceremonial burial practiced amongst these early humans. They added that Neanderthals buried in fully excavated graves often near a fireplace and with food or a piece of meat to be used by the deceased in the afterlife (Caldwell \& Gyles 1966:9). The views of Caldwell and Gyles are further supported by Hultkrantz (1982) who says that Neanderthal had careful burial ceremonies because they might have believed in the afterlife. He cited examples of the cave of Shanidah in northern Iraq where a dead person was buried in a heap of stones resting on the bed of many flowers. Also, the cave Monte Circeo in Italy was found to have contained a human skull within a small circle of stones, an example of the so-called 'skull burial' (Hultkrantz 1982:24). It is difficult to ascertain why Neanderthals buried their dead with items and with elaborative ceremonies except for the idea of the afterlife. ${ }^{18}$

\section{In Ancient Egypt}

Traces of the remains of early humans, from Australopithecus through Homo erectus ('Pekin Man'-type) to the Neanderthal form of $H$. sapiens, have never been found in ancient Egypt (Jordan 1976:28). Redford (2006:11) also says that there are no human remains from the early Ice Age or the Lower Palaeolithic in Egypt. Redford (2006:11) believes that in ancient Egypt, humans first appeared only when they had already developed the ability to manufacture artefacts and to transform their environment, and that this development had taken place about 350000 years ago. ${ }^{19}$ Burland (1957:12-13) also noted that the first people who came to Egypt were Stone Age hunters thus suggesting modern humans. Some scanty archaeological evidence supporting prehistoric human activities in Egypt has been found; the earliest are stone tools and bones. Ordinary hand axes, finer hand axes and flakes of flint have been found from the Kharga Oasis, south of the Fayum and west of Luxor (Jordan 1976:28). These artefacts, in the form of Chellean and Acheulian hand axes, found in the desert and borders of the Nile, present possible evidence of local adaptation in ancient Egypt (Redford 2006:11). ${ }^{20}$

18.Other scholars suggest that the belief in animism is what led to the earliest beliefs in afterlife. Brow (1982:31) explains that animism is the fear that some powerful spirits exist. This could include the fear of the spirit of the dead. Furthermore, Doermann (1961:253) presented the views of Ernest Renan (originally from Renan (1897:130), who suggested that the idea of the soul or spirit, was seen as different entity from the body, has originated from animism (means "the belie that man, and by extension animals, plants and inorganic objects, has a "double, to which the name "soul" is often given. It was by the absence of this "double" that the savage explained the phenomena of sleep, catalepsy and death') (Doermann 1961:253), and that this marked how man, from his animal-like evolutionary state began to believe in the afterlife. But there is little or no evidence to suggest that Neanderthals, the alleged earliest human ancestors to believe in afterlife did so for fear of the spirit of the dead or that Neanderthals practiced animism. Furthermore, it can hardly be proven that other human ancestors like Australopithecus, Pekin Man, $H$. sapiens and many more practiced animism. Therefore, the practice of animism though relevant in the study of the origins of human religion, yet, the practice may not have been responsible for originating the afterlife beliefs amongst modern humans.

19.The same period that the human species was firmly stabilised on earth (Carrington 1963:125).

20.Furthermore, research done on mummified bodies does not give detailed information about the first human occupiers of Egypt because the specific date Egyptians began to mummify is uncertain.
The absence of evidence for the existence of early human ancestors (Australopithecus, H. neanderthalensis, etc.) in ancient Egypt suggests that Egypt was first occupied by modern humans and not necessarily by early human ancestors. The origins of afterlife beliefs in ancient Egypt is at present not fully understood and the absence of evidence for the existence of Neanderthals in Egypt suggests that early human beings who migrated to or lived in Egypt were responsible for introducing and spreading the belief in that region. Mummification is also significant in this regard. During the pre-dynastic period, corpses were simply buried in shallow graves and the natural warm weather of ancient Egypt naturally removed moisture from the corpses (Murnane 1992:37) and this process could be the precursor of applied mummification (Jordan 1976:144-145). The question arises whether the mummification of bodies led to the beliefs in the afterlife or whether the belief in the afterlife led to the practice of mummification. ${ }^{21}$ The answer to the said rhetoric question is still uncertain and under study, but one thing that is certain is, that the development of the process of mummification over a period of time has contributed to the development of Egyptian ideas about the afterlife. Egyptians might have begun to believe in the afterlife before the pre-dynastic period, some time around $8300 \mathrm{BCE}$ through $4500 \mathrm{BCE}^{22}$ (that is before the practice of mummification was formalised). In other words, Egyptians might have begun to believe in the afterlife over 3487 years ago when mummification began to be practiced in Egypt or over 35000 years ago when humans began to intrude Egypt.

\section{Amongst the Yorubas}

Falola and Heaton (2010:17-18) stress that early pioneers of the region of Nigeria have used tools made of wood, bones and stones. Shaw (2004:25-26) added that in Nigeria stone tools were mostly used in the form of pebbles or lumps popularly known as Oldowan-type tools named after the Olduvai Gorge, in Tanzania. Omolewa (2008:15) confirmed that archaeologists have found early stone tools used for hunting in the Jos Plateau, Afikpo in Imo, Iwo Eleru in Ondo and Mejiro in the Old Oyo State. Omolewa, Falola and Heaton believed that the early people that resided in Nigeria used Oldowan-type tools because of the geological evidence that has been found in some parts of Nigeria (at Beli on the River Taraba) showing the age of some rock deposits similar to the Oldowan-type tools (Shaw 2004:25-26). However, the connection between those early inhabitants of Nigeria and the found geological evidence is not proven.

Apart from stone tools, there is evidence of the use of iron tools by humans in Nigeria, and Omolewa (2008:15) thinks that those humans in Nigeria have advanced from the Early

21.Partridge (1994:10) pointed out that the initial purpose of mummification was sanitation and it developed later into preservation. Egyptians believed that preserving the deceased body through mummification helped in the resurrection of the deceased (Davies 1999:27).

22. Boddy (2012) says that the pre-dynastic periods start from 5500 BCE and Scheepers and Scheffler (2000: Glossary section) suggest that the equivalent of the pre-dynastic periods is Pre-Pottery Neolithic ( $8300 \mathrm{BCE}-5000 \mathrm{BCE}$ ) through Pottery Neolithic ( 5500 BCE - 4500 BCE), an equivalent period to Boddy's notion. Pottery Neolithic ( $5500 \mathrm{BCE}-4500 \mathrm{BCE}$ ), an equivalent period to Boddy's notion.
If mummification in ancient Egypt was practiced before $5500 \mathrm{BCE}$, it thus suggests that Egyptians believed in afterlife long before 3487 years ago. 
Stone Age - where they used stone tools - to the Early Iron Age where they began to use metals tools. It is important to note that according to the Nok terracottas the activities of iron smelting in Nigeria is explained but detailed information about the arrival of the first humans to occupy Nigeria cannot be given. It is therefore difficult to estimate exactly the date when humans began to inhabit the various regions of Nigeria, but evidence from the use of Late Stone Age objects (65 000 $\mathrm{BCE})$, the Iwo Eleru rock (9000 BCE), animal husbandry since 3000 BCE - 2000 BCE and evidence from Nok sculptures (500 $B C E-200 C E)^{23}$ all suggest that humans have lived in Nigeria before the Stone Age civilisation 65000 BCE (cf. Omolewa 2008:15). With regard to the regions occupied by the Yorubas of Nigeria, one of the first human remains was found in a cave at Iwo Eleru rock (in Yorubaland) and has been dated to 9000 BCE. Based on Falola and Heaton's findings, early humans must have lived in Iwo Eleru long before 9000 BCE (Falola \& Heaton 2010:19). ${ }^{24}$ The discovery was made in 1965. The burial site is associated with microlithic industry and, although a detailed report has yet to be released, preliminary examination suggests that the remains are Negroid in character (Clark 1970:165). If the remains are assumed to be those of the ancestors of the Yorubas, this does not provide enough knowledge on when and on how to Yorubas began to believe in the afterlife.

\section{Conclusion}

This research has not been able to establish clearly the claim that Egyptians migrated or had contact with Yoruba ancestors or Yoruba people. One cannot identify specific individuals both of Egyptian or Yoruba origins who met either in Yorubaland or in Egypt. It is indeed a fact that certain Yoruba cultures like the afterlife beliefs, languages, customs and many more are similar yet there are few differences that exist between these two cultures. The absence of clear ancient times migration routes from North Africa and from Egypt to Kanem Borno in Nigeria and most importantly from Kanem Borno to Yorubaland poses a serious challenge to the ideas that the Egyptians gave rise to the Yoruba people and their culture; it also raises questions about the credibility of the Oduduwa legend whereby the origin of the main character in the legend is credited to have come from Egypt or Mecca. ${ }^{25}$ Lucas (1970:373) believes that all West African culture including those of the Yorubas had some primitive origins and that it is illogical to think that each tribe in West Africa was responsible for forming an independent culture. He noted that differences found in some West African cultures are due to the fact that no culture is static. This could have been the reason which made Lucas and other writers think that Yoruba culture did not originate or develop independently.

23.Dates from Michael Omolewa (2006:9-11) and Clark (1970:215).

24.At present, one of the most favourable evidences for early afterlife practice amongst the Yorubas are the remains found in Iwo Eleru which is dated to 9000 $\mathrm{BCE}$. The remains suggest that the early occupiers of Yorubaland might have believed in the afterlife long before 6987 years ago.

25.Oduduwa met people who lived in Yorubaland, these unknown people might have had their cultures, and hence Oduduwa is not responsible for originating their cultures. There is no evidence about how he influenced those people culturally. This might have been why Ayandele (2004:123) says that the Oduduwa legend is not aimed at tracing the origins of the Yorubas but is aimed at showing a stage of not aimed at tracing the origins of the Yorubas but is aimed at showing
Oduduwa's monarchical hierarchy of the early Yoruba kingdom of Ile Ife.
Therefore, many Yoruba people I interviewed said that they originated in Egypt or 'east', and researchers like Lucas, Johnson, Folorunso, Parrinder and Frobenius who relied on cultural comparison say that the Yorubas were highly influenced by the Egyptians or by Etruscan culture or that the Yorubas originated in Egypt, ${ }^{26}$ have succeeded in openingup an academic spark with regard to the origins of Yoruba culture which needs more investigation.

This researcher is not disputing the possibility that the Yoruba culture might have been influenced by some foreign cultures, but in the absence of evidence of contact between Etruscans or ancient Egyptians and the Yorubas; he is of the opinion that Yoruba afterlife culture has originated through the process of 'parallel evolution'. The idea of parallel evolution teaches that the same species of early human ancestors evolved in various locations and developed abilities and characters that suited their specific environmental needs. ${ }^{27}$ The rainforest nature of many parts of West Africa including the Yorubaland (cf. Shinnie 1965:76) might have attracted the existence of early humans, and it is no surprise that Clark (1970:120-122) suggests that Neanderthals lived in the higher regions of West Africa and that West Africa is the place where the African Negro evolved from Neanderthal species. ${ }^{28}$ Fossils of early human ancestors, particularly of Australopithecus, were also found in Lake Chad (Pfeiffer 1970:94), a geographical neighbour of Nigeria. It is yet to be proven, that Neanderthals might have lived in Nigeria (Yorubaland) and developed their afterlife beliefs according to their environmental challenges. ${ }^{29}$ This explains why differences exist (like punishment in the afterlife, fear of the spirit of the dead, ${ }^{30}$ reincarnation, mummification and building of pyramids) between the Egyptian and Yoruba afterlife beliefs. The similarities in the afterlife beliefs between these two cultures exist because Neanderthals were globally of various species yet they are the same beings with the same beliefs and they are responsible for originating and spreading the afterlife beliefs in Yorubaland.

In conclusion, this researcher is of the opinion that the Egyptians are not the originators or founders of afterlife

26.The Yoruba earlier burial practices like wrapping of a corpse in a mat, the lack of burial chambers or pyramids, the lack of complicated rituals during burial, the building of simple tombs, the lack of mummification, the burial of a corpse with few objects, and with the loyalists of the deceased, and the removal of certain body parts of the deceased, have strong Egyptian pre-dynastic connections. Complicated burials started in Egypt at the end of dynastic periods and some of these practices of elaborate burials also found their way amongst later Yorubas. these practices This is the main reason that made Parrinder (1951:200-203) believe that migration between ancient Egyptians and the Yorubas took place during the pre-dynastic and
Dynastic periods.

27.Carrington (1963:137-142.

28.More research, especially pertaining to human origins, needs to be conducted in West Africa. This researcher believes that there are likely to be many remains of early human ancestors lying on West African soil and even in Yorubaland. This call is necessary because West Africa has suffered neglect in research, for example, the non-permanent settlement of European explorers on West African shores (Boateng 1978:102), the non-documentation by classical writers about West African history (Lange 2004:319) and the lack of much archaeological evidence (Shaw 2004:52) have contributed to this neglect.

29.There could be more and older human remains in Yorubaland than the 9000 BCE Iwo Eleru remains. More archaeological search will be relevant in Yorubaland in this regard.

30.Carrington says that Neanderthal burial practices involving burial of the deceased with the skeletons of bears suggest that Neanderthals had ideas about fear of with the skeletons of bears suggest that Neanderthals had ideas about fear of
the spirit of the dead (Carrington 1963:110-111) like the Yorubas and unlike the ancient Egyptians. 
beliefs and they did not influence or are the origin of Yoruba afterlife beliefs. This researcher believes that Neanderthals or some similar kinds of early humans lived in Nigeria (Yorubaland) and they introduced or influenced Yoruba afterlife beliefs through some forms of interbreeding by the unknown earlier occupiers of Yorubaland. ${ }^{31}$ Early ancestors of the Yorubas continued to develop their afterlife beliefs according to their cognitive understanding with regard to their environments, for example, Egyptian climate supported mummification unlike in Yorubaland. More studies need to be carried out in this regard.

\section{Acknowledgements \\ Competing interests}

The author declares that he has no financial or personal relationship(s) which may have inappropriately influenced him in writing this article.

\section{References}

Adamolekun, K., 2001, 'Survivors' motives for extravagant funerals among the Yorubas of Western Nigeria', Death Studies 25(7), 609-619 http://dx.doi.org/10.1080/074 81180126579,PMid:11813709

Ade, D.P., 2006, 'Change and continuity: The Yoruba belief in life after death', lecture held at the Metaxus Institute Philadelphia, 03-07 June, pp. 1-15, viewed 29 May 2013 from http://www.scripd.com/doc59067767/Dopa-Mu

Adedeji, J.A., 1983, 'The Egungun in the religious concept of the Yoruba', in E.A.A. Adeghola (ed.), Traditional religion in West Africa, pp. 117-127, Daystar, Ibadan.

Agai, J.M., 2005, 'Christian responses to the biological theory of human evolution', MTH thesis, Department of Church History, Theological College of Northern Nigeria.

Agai, J.M., 2011, 'Rethinking the concepts of Sheol and Gehenna in the Hebrew Bible in the light of its impacts in Christian thinking', Theologia Viatorum 35(2), 174200.

Akintoye, S.A., 2004, 'From early times to the 20th century', in N.S. Lawal, M.N.O. Sadiku \& A. Dopamu (eds.), Understanding Yoruba life and culture, pp. 3-30, African World Press, Trenton.

Ayandele, E.A., 2004, 'Yorubaland up to 1800', in I. Obaro (ed.), Groundwork of Nigeria history, pp. 121-143, Heinemann Educational Books, Jos.

Asakitikpi, A.E., 2008, 'Born to die: The Ogbanje phenomenon and its implication on childhood mortality in southern Nigeria,' Anthropologist 10(1), 59-63.

Awolalu, O.F., 1979, Yoruba beliefs and sacrificial rites, Longman Group Limited, London.

Boateng, E.A., 1978, A political geography of Africa, Cambridge University Press, London.

Boddy, A., 2012. 'Ancient Egypt: Predynastic period (5500-3100BCE)', in About com, viewed 22 December 2012, from http://africanhistory.about.com/od/ egyptology/a/PreDynasticEgypt.htm.

Boshoff, W. \& Scheffler, E., 2000, 'The world of the ancient near east', in E. Boshoff, E. Scheffler \& I. Spangenberg (eds.), Ancient Israelites literature in context, pp. 18-57, Protea Book House, Pretoria.

Brow, R., 1982, 'Origins of religion', in R. Beaver (ed.), Eerdmans handbook to the world's religions, pp. 31-48, Lion Publishers, Oxford.

Burland, C.A., 1957, Ancient Egypt, Hulton Educational, London.

Caldwell, E. \& Gyles, W., 1966, The ancient world, Holt, Rinehart \& Winston Inc., New York.

Carrington, R., 1963. A million years of man: The story of human development as a part of nature, Weidenfeld \& Nicolson, London.

Clark, J.D., 1970, The prehistory of Africa: Ancient peoples and places, Thames and Hudson, London.

31.Whilst Neanderthals were living in Europe, other more modern-looking humans (like the Rhodesian Man from the Broken Hill in Zambia) were as well living in Africa during the same period. Bones of skulls and limbs from Saldanha in South Africa, during the same parica, Ngaloba in Tanzania, Bodo and the Omo Valley in Ethiopia all reveal that early particular also experienced the pioneering impacts of these early humans.
Constable, G., 1973, The Neanderthals: The emergence of man, Time Life, New York.

Davies, J., 1999, Death, burial and rebirth in the religions of antiquity, Taylor \& Francis, New York.

Doermann, R.W., 1961, 'Sheol in the Old Testament', PhD dissertation, Department of Theological Studies, Duke University.

Ellis, A. B., 1966, The Yoruba-speaking peoples of the slave coast of West Africa, their religion, manners, customs, laws, language, etc., Anthropological Publishers, religion, mant.

El-Shahawy, A., 2005, The funerary art of ancient Egypt: A bridge to the realm of the hereafter, Farid Atiya, Cairo.

Fagg, B., 1977, Nok terracottas, Ethnographica Ltd., Lagos.

Falola, T. \& Heaton, M.M., 2010, A history of Nigeria, Cambridge University Press, Cambridge.

Folorunso, C.A., 2003, 'Views of Ancient Egypt from a West African Perspective', in D. O'Connor \& A. Reid (eds.), Ancient Egypt in Africa, pp. 77-94, University College London, London.

Frobenius, L., 1968, The voice of Africa: Being an account of the travels of the German inner African expedition in the years 1910-1912, vol. 1, Benjamin Blom, New York.

Hultkrantz, A., 1982, 'Religion before history', in R.P. Beaver (ed.), Eerdman's handbook to the world's religions, pp. 22-29, Lion, Herts.

James, T.G.H., 1976, An introduction to ancient Egypt, Harper \& Row, New York.

Johnson, S., 2001, The history of the Yorubas: From the earliest times to the beginning of the British protectorate, CSS, Abuja.

Jordan, P., 1976, Egypt the black land, Phaidon, Oxford.

Lavers, J.E., 2004, 'Kanem and Borno to 1800 ' in O. Ikime (eds.) Groundwork of Nigerian history, pp. 187-209, Heinemann Educational Books, Jos.

Lange, D., 2004, Ancient kingdoms of West Africa: Africa-centred and CanaaniteIsraelite perspectives, a collection of published and unpublished studies in English and French, J.H.Roll, Dettelbach.

Leakey, R.E., 1982, Human origins, Hamish Hamilton, London.

Le Roux, M., 2008, 'Ancient near eastern influence in sub-Saharan Africa' Ekklesiastikos Pharos 90(19), 1-20.

Lucas, J.O., 1948, The religion of the Yorubas: Being an account of the religious beliefs and practice of the Yoruba peoples of southern Nigeria, especially in relation to the religion of ancient Egypt, Christian Missionary Society, Lagos.

Lucas, J.O., 1970, Religions in West Africa \& ancient Egypt, n.p., Lagos.

MacGregor, G., 1992, Images of afterlife, Paragon, New York.

Murnane, W.J., 1992, 'Taking it with you: The Problem of Death and Afterlife in Ancient Egypt', in $\mathrm{H}$. Obayashi (ed.), Death and afterlife: Perspectives of world religions, pp. 35-48. Greenwood Press, New York.

Omolewa, M., 2008, Certificate history of Nigeria, Longman, Ikeja.

Otey, T., 2004, 'Ancient Egyptian Funerary Customs', viewed 09 June 2008, from http://www.charlotte.nc.us/History/Egypt/04/otey/htm.

Ojo, A., 1999, 'Yoruba Omo Oduduwa: Papers on Yoruba people, language, and culture', in The University of Georgia, viewed 09 June 2008, from http://www.uga. edu/aflang/YORUBA/ODUDUWA.htm.

Parrinder, G., 1942, West African religion: A study of the beliefs and practices of Akan, Ewe, Yoruba, Ibo, and kindred Peoples, Epworth, London.

Parrinder, G., 1951, West African psychology: A comparative study of psychological and religious thought, Lutterworth, London.

Partridge, R.B., 1994, Faces of Pharaohs: Royal mummies \& coffins from ancient Thebes, The Rubison London.

Pfeiffer, J.G., 1970, The emergence of man, Thomas Nelson \& Sons, Nairobi.

Raven, P.H. \& Johnson, B.G., 1999, Biology, 5th edn., WCB McGraw-Hill, New York. PMCid:1171219

Redford, D.B., 2006, A history of ancient Egypt: Egyptian civilisation in context, Penn State University Press, Pennsylvania.

Renan, E., 1897, Histoire du people d' Israel, vol. 5, Calman-Levy, Paris.

Roberts, G.R., 2013, 'A history of the Etruscan people including their cities, art, society, rulers and contributions to civilization', in International world History Project, viewed 12 January 2013, from http://history-world.org/etruscan.htm.

Shaw, T., 2004, 'Prehistory', in O. Ikime (ed.), Groundwork of Nigerian history, pp. 25-53. Heinemann Educational Books, Jos.

Scheffler, E., 2000, Fascinating discoveries from the biblical world, Biblia, Pretoria. PMCid:101787

Scheepers, C. \& Scheffler, E., 2000, From Dan to Beersheba: An archaeological tour of ancient Israel, Biblia, Pretoria.

Shinnie, M., 1965, Ancient African kingdoms, Edward Arnold, London.

Umoh, S.M., 1971, 'Nigeria's multi-ethno-cultural communications system and its influence upon social and business behaviour', PhD dissertation, Department of Communications, United State International University.

Wadud, A., 1971, Phenomenon of nature and the Quran, Seyed Khatid Wadud, Lahore.

Wayne, S. \& Simonis, D., 1994, Egypt and the Sudan-a travel survival kit, Lonely Planet, Paris. 